\title{
Health care-seeking patterns for female genital mutilation/cutting among young Somalis in Norway
}

Vivian N. Mbanya ${ }^{1 *}$, Abdi A. Gele ${ }^{2,3}$, Esperanza Diaz $^{3,4}$ and Bernadette Kumar ${ }^{1,4}$

\begin{abstract}
Background: Female genital mutilation/cutting (FGM/C) is a great concern, considering all the potential health implications. Use of health care services related to FGM/C by women who have been subjected to FGM/C in Norway remains to be understood. This study aims to explore the health care-seeking patterns for FGM/C-related health care problems, among young Somalis in Norway.
\end{abstract}

Methods: A cross-sectional study involving 325 young Somalis in Oslo was conducted in 2014 using respondentdriven sampling (RDS) technique. The RDS was initiated by a small number of recruited seeds, who were given coded coupons to recruit their peers to participate in the study. Eligible recruiters who participated in the study and redeemed their coupons created the first wave of respondents. The first wave further recruited their peers, the second wave. The cycle continued to attain the needed samples. Using interviews and structured questionnaires, data on socio-demographic, FGM/C status and FGM/C-related use of health care were obtained. Logistic regressions were used to compute the odds ratio $(\mathrm{OR})$ and the confidence interval $(\mathrm{Cl})$ for the associations between demographic variables, to circumcision status and health care-seeking for FGM/C. This study will focus on the 159 female participants of the total 325.

Results: While $51.6 \%$ of the 159 women were subjected to FGM/C, only $20.3 \%$ of them used health care services for FGM/C-related problems. Women's FGM/C status was associated with age $\geq 12$ years at migration, experience of stigma regarding FGM/C practice $(p<0.05)$, support of FGM/C practice, and place of birth of women $(p<0.05)$.

Conclusion: Only one-fifth of the women with FGM/C sought care for FGM/C-related health problems. Our study does not provide the answers to why only a few of them sought care for FGM/C. However, as a large proportion of women did not seek care, it is important to investigate the reasons for this. For, we propose to conduct further research targeting girls and women who have undergone FGM/C to assess challenges in accessing health care services for proper intervention.

Keywords: Female circumcision, Care-seeking, Immigrants, Somalis, Norway

\section{Background}

Female genital mutilation/cutting (FGM/C) is a global health concern with numerous health and ethical implications. An estimated 200 million girls and women in 30 countries in Africa and some parts of Asia are affected by FGM/C. The practice is carried out mostly on young girls, between infancy and adolescence, with 3 million girls

\footnotetext{
* Correspondence: vivimbanya@yahoo.com; v.n.mbanya@medisin.uio.no 'Department of Community Medicine and Global health, Institute of Health and Society, Faculty of Medicine, University of Oslo, P.O Box 1130, Blindern, 0318 Oslo, Norway

Full list of author information is available at the end of the article
}

estimated to be at risk annually [1, 2]. FGM/C varies among countries, with Somalia, having the highest prevalence in the world [3]. Owing to globalized migratory processes, the tradition of $\mathrm{FGM} / \mathrm{C}$ has spread to other countries, including countries in Europe and North America. Available national studies in the EU reveal prevalence rates for FGM/C among migrants of up to 49\% [4].

According to WHO, FGM/C practice, "comprises all procedures involving partial or total removal of the external female genitalia or other injury to the female genital organs for non-medical reasons" [1]. There are four types of FGM/

(C) The Author(s). 2018 Open Access This article is distributed under the terms of the Creative Commons Attribution 4.0 International License (http://creativecommons.org/licenses/by/4.0/), which permits unrestricted use, distribution, and 
C: Type 1 involves the partial or total removal of the clitoris and the prepuce. Type 2 involves the partial or total removal of the clitoris and the labia minora. Type 3 (infibulation) is the most severe form, which involves the removal and the opposition of the inner and outer labia, with or without excision of the clitoris, leading to the creation of a covering seal and narrowing of the vagina opening. Type 4 incorporates all other harmful procedures to the genitalia [2]. The various forms of FGM/C can occur in different combinations and they are not practice to the same extent everywhere. The reason for the practice varies considerably between religion, ethnic groups, countries, and regions and the practice and the age at which girls are cut depends on the prevailing tradition of the area $[5,6]$. While studies have demonstrated the immediate, obstetric, gynecological and psychological harmful health effects of FGM/C practices, long-term effects may vary [7-9]. The immediate complications involve hemorrhage, pain, shock, genital tissue swelling, infections, urination problems, and death. Other possible complications are sexual problems as dyspareunia, decreased sexual satisfaction, reduced sexual desire and arousal [10, 11]. A number of studies in Norway and abroad have shown the association between FGM $\backslash \mathrm{C}$ and adverse obstetric outcomes, including episiotomy, prolonged labor, obstetric tears/lacerations and difficult labor/ dystocia [12]. Following circumcision, women have been reported to suffer from post-traumatic stress disorder (PTSD) , depression, loss of trust, lack of bodily well-being and permanent lifetime tissue damage [13].

Because FGM/C remains a pressing human right and public health issue, it is imperative for the societies and the international bodies to prohibit it by law $[14,15]$. Performing any form of FGM/C in Norway is forbidden and punishable by law, with an incarceration term of up to 6 years and 15 years for severe cases [16]. However, according to the Norwegian Directorate of Immigration, many girls and women migrating from FGM/C practicing countries may have undergone FGM/C upon arrival in Norway [16]. There were 44,467 female immigrants from FGM/C practicing countries residing in Norway in 2013, of which $50 \%$ were estimated to have been subjected to Type 3 prior to migration [17]. A recent study in Norway indicates that 17,300 of women and girls who have undergone FGM/C can be in need of health care, $[17,18]$.

Health care-seeking behavior can be defined as a "sequence of remedial actions that individuals undertake to rectify perceived ill health" [19]. The Norwegian health system provides services for FGM/C care and FGM/Crelated issues. Those who have undergone $\mathrm{FGM} / \mathrm{C}$, receive important information about the prohibition by legislation, the health consequences and health care provision related to $\mathrm{FGM} / \mathrm{C}$. They also receive the necessary health care and free treatment related to FGM/C [16]. Medical services are available to contact and talk about FGM/C and to get the right treatment. Women can contact their general practitioner, midwife/nurses at the local medical center or a school nurse. They can also contact the women's or children's clinic at their local hospital [16]. Women must be referred by their general practitioner (GP) to these specialized services. While health care provider's experiences with women living with FGM/C during birth have been reported elsewhere [20], the health care-seeking pattern among women who have been subjected to FGM/C has not been explored. This study aims to explore the health care-seeking patterns for FGM/C-related health care problems, among young Somalis living in Norway.

\section{Methods}

\section{Setting/study population}

Participants were Somali women and men who took part in a cross-sectional study conducted in 2014 in Oslo using a respondent-driven sampling (RDS) technique. The RDS technique consists of an enhanced snowball sampling, in which information on who recruited whom and the individual social network size, provided the basis for the calculation of inclusion probability and minimally biased population indicators, as well as the variability of these indicators $[21,22]$. The RDS was initiated by a small number of purposely recruited seeds, who were given uniquely coded coupons and incentives to recruit their peers to participate in the study. Eligible recruits who participated in the study and redeemed their coupons created the first wave of respondents. The first wave respondents were given incentives to further recruit their peers [21], who then formed the second wave, with the cycle continuing until the proposed sample size was achieved. RDS is largely used in behavioral studies [23], and it is widely acknowledged for its potential in studying immigrant communities whose sampling frame is unavailable [24-27].

\section{Inclusion criteria}

Eligibility criteria for the study was being of Somali origin, permanently or legally residing in the Oslo municipality, between the ages 16 to 25 years, willing to participate and able to provide informed consent.

\section{Recruitment process}

Four eligible seeds, comprising socially well-connected individuals, were selected based on a diversity of gender, location, years of stay in Norway and age. After providing informed consent, the seeds underwent an interview and were educated on how to further recruit other eligible young Somalis. They were given two uniquely coded coupons to help recruit their peers in their social network. The reason for using only two coupons was to elongate the recruitment waves so that the diversion of 
subsequent waves from the initial seeds was increased. Each seed proceeded to recruit two persons into their network, which became the first wave, with the firstwave participants further recruiting their peers, which then became the second wave. Each participant was compensated with 100 Norwegian kroner (NOK) for participating in the study and received an additional 100 NOK for each recruited peer who met the eligibility criteria and participated in the study. With $95 \%$ level of confidence and 5\% margin of error, we obtained a desired sample size of 325 . In this paper, the focus will be on the women participants.

\section{Variables}

- FGM/C status was denoted as "yes/no" in reference to having been circumcised or not.

- Health care-seeking was denoted as "yes/no" in reference to having visited a GP or being referred for $\mathrm{FGM} / \mathrm{C}$ health related issues.

- Support of FGM/C practice was denoted as "yes/no" in reference to participant's opinion in encouraging the continuation or the discontinuation of the practice of FGM/C.

- Stigmatized by FGM/C practice was denoted as "yes/no" in reference to feeling stigmatized because of FGM/C practice.

\section{Data analysis}

Descriptive statistics in the form of frequencies (percentages) and means with standard deviations were used to summarize the data at baseline. Chi-square tests and Fishers' exact test (where appropriate) were used to establish an association between the FGM/C status and the socio-demographic variables. Generalized linear regression models (GLMs) with the logit function were used to fit binary responses relating to FGM/C and health care-seeking for FGM/C. Possible demographic factors that were associated with the response variables were identified and explained. The modeling process proceeded in two steps; first, simple GLMs were used to identify socio-demographics factors with $P \leq 0.05$ for the FGM/C model. Secondly, variables that were significant $(\mathrm{P} \leq 0.05)$ in the univariate analyses together with independent variables that have been previously shown to be associated with FGM/C were used to fit model 2. However, model 2 for the health care-seeking for FGM/C was based on independent variables with $P \leq 0.20$. We used $\mathrm{P} \leq 0.20$ in order not to miss out important variables. Model 1 (full model) was adjusted for all socio-demographic factors. We used the Akaike information criterion (AIC) to select a better fit between model 1 and model 2. The AIC states that given a set of candidate models, the model with the smallest AIC estimate fits the data better. All analyses were performed using SPSS IBM Statistics 24 and the significance level was set at 0.05 .

\section{Results}

\section{Sample characteristics}

The general characteristics of participants are summarized in Table 1. In this article, we have chosen to focus upon the results from the 159 women. Of the study participants, $51.1 \%$ were men and $48.9 \%$ were women, with a mean age of 19.7 (SD 1.90). Compared to the men, the women were slightly younger (19.3 vs. 20.0 years). The majority of the women $(56.7 \%)$ had secondary education. $33.3 \%$ of the women were born in Norway while $66.7 \%$ migrated to Norway. The women's mean age at migration was 11.07 (SD 4.7) years and $81.5 \%$ of them were single.

\section{Association between FGM/C and socio- demographic characteristics}

Among women in the study, $51.6 \%$ had been circumcised, while $48.4 \%$ were not circumcised. Using Chisquare statistic, significantly a higher proportion of the circumcised women were born out of Norway and were 12 years or older at migration as compared to those born in Norway and earlier age of migration respectively. Circumcised women more often supported the practice

Table 1 Demographic characteristic of the study population

\begin{tabular}{|c|c|c|c|}
\hline Variables & $\begin{array}{l}\text { Male } \\
(n=166)\end{array}$ & $\begin{array}{l}\text { Female } \\
(n=159)\end{array}$ & $\begin{array}{l}\text { Total } \\
(n=325)\end{array}$ \\
\hline \multicolumn{4}{|l|}{ Place of birth, (\%) } \\
\hline Born in Norway & 44.6 & 33.3 & 39.2 \\
\hline Born out of Norway & 55.4 & 66.7 & 60.8 \\
\hline Age, $($ mean $\pm S D)$ & $20.0 \pm 1.74$ & $19.3 \pm 1.98$ & $19.7 \pm 1.90$ \\
\hline $\begin{array}{l}\text { Age at migration to Norway, } \\
\text { (mean } \pm S D)\end{array}$ & $13.43 \pm 4.8$ & $11.07 \pm 4.7$ & $12.20 \pm 4.91$ \\
\hline \multicolumn{4}{|l|}{ Marital status, (\%) } \\
\hline Single & 62.5 & 81.5 & 71.7 \\
\hline Married & 30.6 & 17.2 & 24.1 \\
\hline Divorced & 6.9 & 1.3 & 4.2 \\
\hline \multicolumn{4}{|l|}{ Education, (\%) } \\
\hline University & 16.9 & 13.4 & 15.2 \\
\hline Secondary & 51.2 & 56.7 & 53.9 \\
\hline Primary & 30.1 & 26.1 & 28.2 \\
\hline No formal education & 1.8 & 3.8 & 2.8 \\
\hline Subjected to genital cutting, (\%) & - & 51.6 & 51.6 \\
\hline Support of FGM/C practices, (\%) & 7.3 & 10.8 & 9.0 \\
\hline \multicolumn{4}{|l|}{ Stigmatized of FGM/C practice, (\%) } \\
\hline No & 67.7 & 79.1 & 73.2 \\
\hline Yes & 32.3 & 20.9 & 26.8 \\
\hline
\end{tabular}


of FGM/C. No significant differences between women who were or were not circumcised were found regarding education level, marital statuses or stigma of the FGM/C practice, Table 2 .

Table 3 shows the odds ratios (OR) and their 95\% CIs obtained from the binary logistic regression analyses. The unadjusted analyses showed that age at migration, support of FGM/C practice and place of birth were significantly associated with FGM/C. Based on the AIC, we present results from model 2 . The analysis showed that participants who were at least 12 years when they migrated to Norway were almost 5-times likely to have undergone FGM/C compared with participants who were less than 12 years when they migrated to Norway $(P=0.01)$. We also observed that being born in Norway significantly reduced the odds of FGM/C by $98 \%$.

\section{Health care-seeking for FGM/C}

Out of the $51.6 \%$ subjected to $\mathrm{FGM} / \mathrm{C}, 20.3 \%$ of the circumcised women accepted with a "yes" to have sought help for health problems related to FGM/C. Table 4 presents Chi-square statistics for the association of demographic variables and FGM/C health care-seeking. The odds ratios presented in Table 5 show the association between health care-seeking for FGM/C and socio-demographic factors. In the unadjusted analyses, age at migration to Norway and stigma of FGM/C practices were significantly associated with health care-seeking for FGM/C. Model 2 was also selected because it has a smaller AIC estimate. The odds for health care-seeking for FGM/C were 3.18 times higher for participants who had migrated to Norway when they were $\geq 12$ years old compared with those who were $<$ 12 years old $(P=0.05)$. The analysis also showed that stigma of FGM/C practices significantly increased the likelihood of health care-seeking for FGM/C by 5 -times.

\section{Discussion}

FGM/C remains a common practice in the countries where it is traditionally performed [28], but the tradition is seldom maintained after migration $[29,30]$. Despite the

Table 2 Proportion of circumcised women across demographic variables

\begin{tabular}{|c|c|c|c|c|}
\hline \multirow[t]{2}{*}{ Socio- demographic characteristic of women } & \multicolumn{2}{|l|}{ Women FGM/C status } & \multirow[t]{2}{*}{ Statistics } & \multirow[t]{2}{*}{$P$-value } \\
\hline & Circumcised $(n=82)$ & Not circumcised $(n=77)$ & & \\
\hline Health care-seeking for FGM/C-related health problems & $16(20.3)$ & - & - & - \\
\hline Place of birth: & & & $X^{2}=64.12$ & $<0.0001$ \\
\hline Born in Norway & $3(3.8)$ & $48(64.9)$ & & \\
\hline Born out of Norway & $76(96.2)$ & $26(35.1)$ & & \\
\hline Age distribution (years): & & & $x^{2}=0.01$ & 0.89 \\
\hline 16 to 20 & $56(69.1)$ & $54(70.1)$ & & \\
\hline 21 to 25 & $25(30.9)$ & $23(29.9)$ & & \\
\hline Age at migration to Norway & & & $X^{2}=37.82$ & $<0.0001$ \\
\hline 0 to 11 years & $37(45.1)$ & $70(90.9)$ & & \\
\hline$\geq 12$ years & $45(54.9)$ & $7(9.1)$ & & \\
\hline Education: & & & Fisher's Exact & 0.27 \\
\hline University & $8(10.0)$ & $13(16.9)$ & & \\
\hline Secondary & $43(53.8)$ & $46(59.7)$ & & \\
\hline Primary & $25(31.3)$ & $16(20.8)$ & & \\
\hline Informal education & $4(5.0)$ & $2(2.6)$ & & \\
\hline Marital status: & & & Fisher's Exact & 0.98 \\
\hline Single & $64(81.0)$ & $59(81.9)$ & & \\
\hline Married & $14(17.7)$ & $12(16.7)$ & & \\
\hline Divorce & $1(1.3)$ & $1(1.4)$ & & \\
\hline Women in support of FGM/C: & & & $x^{2}=7.63$ & 0.007 \\
\hline No & $67(82.7)$ & 74(96.1) & & \\
\hline Yes & $14(17.3)$ & $3(3.9)$ & & \\
\hline Women stigmatized of FGM/C practice: & & & $X^{2}=1.14$ & 0.28 \\
\hline No & $59(75.6)$ & $62(82.7)$ & & \\
\hline Yes & $19(24.4)$ & $13(17.3)$ & & \\
\hline
\end{tabular}


Table 3 Logistic regression analyses for the associations between demographic variables and female genital mutilation/cutting

\begin{tabular}{|c|c|c|c|c|c|c|}
\hline \multicolumn{7}{|c|}{ Female genital mutilation/cutting } \\
\hline \multirow[t]{3}{*}{ Demographic variables } & \multicolumn{2}{|c|}{ Univariate analysis (unadjusted) } & \multirow{2}{*}{\multicolumn{2}{|c|}{$\begin{array}{l}\text { Model } 1 \text { (Adjusted) } \\
{ }^{\mathrm{a}} \mathrm{AIC}=118.34\end{array}$}} & \multirow{2}{*}{\multicolumn{2}{|c|}{$\begin{array}{l}\text { Model } 2 \text { (Adjusted) } \\
{ }^{\mathrm{a}} \mathrm{AIC}=116.70\end{array}$}} \\
\hline & \multirow[b]{2}{*}{ OR $(95 \% \mathrm{Cl})$} & \multirow[b]{2}{*}{$P$-value } & & & & \\
\hline & & & $\overline{O R}(95 \% \mathrm{Cl})$ & $P$-value & $\overline{\mathrm{OR}}(95 \% \mathrm{Cl})$ & $P$-value \\
\hline \multicolumn{7}{|l|}{$\overline{\text { Age }}$} \\
\hline 16 to 20 years & 1 & & 1 & & 1 & \\
\hline 21 to 25 years & $1.04(0.53-2.06)$ & 0.89 & $0.80(0.23,2.70)$ & 0.71 & $1.20(0.37,3.84)$ & 0.76 \\
\hline \multicolumn{7}{|c|}{ Age at migration to Norway } \\
\hline 0 to 11 years & 1 & & 1 & & 1 & \\
\hline$\geq 12$ years & $12.16(4.99-29.62)$ & $<0.01$ & $4.78(1.53,15.00)$ & 0.01 & $4.84(1.57,14.91)$ & 0.01 \\
\hline \multicolumn{7}{|l|}{ Marital status } \\
\hline Single & 1 & & 1 & & 1 & \\
\hline Married & $1.07(0.46-2.51)$ & 0.86 & $0.86(0.23,3.21)$ & 0.82 & $0.71(0.20,2.51)$ & 0.60 \\
\hline Divorce & $0.92(0.05-15.07)$ & 0.95 & - & - & - & - \\
\hline \multicolumn{7}{|c|}{ Support of FGM/C practice } \\
\hline No & 1 & & 1 & & 1 & \\
\hline Yes & $5.15(1.41-18.72)$ & 0.01 & $2.06(0.38,11.10)$ & 0.40 & $2.10(0.39-11.43)$ & 0.39 \\
\hline \multicolumn{7}{|l|}{ Education } \\
\hline University & 1 & & 1 & & 1 & \\
\hline Secondary & $1.51(0.57-4.02)$ & 0.40 & $1.44(0.32,6.42)$ & 0.64 & $1.73(0.40,7.43)$ & 0.46 \\
\hline Primary & $2.53(0.86-7.48)$ & 0.09 & $2.72(0.48,15.51)$ & 0.26 & $3.06(0.57,16.38)$ & 0.19 \\
\hline No formal education & $3.25(0.48-21.9)$ & 0.22 & $10.34(0.17,618.48)$ & 0.26 & $10.19(0.46,227.76)$ & 0.14 \\
\hline \multicolumn{7}{|l|}{ Place of birth of women } \\
\hline Born out of Norway & 1 & & 1 & & 1 & \\
\hline Born in Norway & $0.02(0.01,0.07)$ & $<0.01$ & $0.01(0.001,0.10)$ & $<0.01$ & $0.02(0.005,0.12)$ & $<0.01$ \\
\hline \multicolumn{7}{|c|}{ Stigmatized of FGM/C practice } \\
\hline No & 1 & & 1 & & & \\
\hline Yes & $1.53(0.69-3.38)$ & 0.28 & $2.58(0.59,11.28)$ & 0.21 & & \\
\hline
\end{tabular}

Model 1 is a full adjustment for all main demographic variables

Model 2 is based on variables that are statistically significant from the univariate analysis and variables that have been shown to be associated with FGM/C in the literature

${ }^{a}$ Model selection was based on the Akaike Information Criterion (AIC) which states that a model with a smaller AIC estimate fits the data better. Therefore, based on the AIC, model 2 was selected

worlds' effort to discourage $\mathrm{FGM} / \mathrm{C}$, it remains a traditional norm deeply rooted within the culture and the tradition of the communities within the Horn of Africa [31-33]. In our study we found that of the total number of women with FGM/C in this study, fewer (20.3\%) sought assistant for FGM/C-related health problems, although, some might have concealed they had sought treatment. The reasons for the fewer number of women using the health services are not understood, but, this could relate to a number of factors [20,34]. Socio-cultural factors, associated with beliefs, expectations and values with regard to health, can be important in understanding the reasons for the fewer number of women using the health care services in the current study.

Based on the smallest AIC estimates in the current study, variations in $\mathrm{FGM} / \mathrm{C}$ status across several characteristics were functions of the place of birth of women and age at migration with circumcised women predominantly among those born out of Norway and among those who migrated from the age of 12 years. FGM/C practice is unlikely to occur in Norway because migration has most likely brought a change in the FGM/C practice, due to the contextual effects of FGM/C such as its illegality, awareness, women's educational status, women's readiness for the discontinuity of the practice in Norway. Cases of FGM/C reported to the police between 2005 and 2016, were dropped because of lack of evidence and no criminal offenses were proven. To the best of our knowledge no case has been tried in the Norwegian courts so far [35]. Although our analysis reveals that women who supported the practice were more likely to be circumcised, it is noteworthy that the majority of the women who have 
Table 4 Demographic variables and association to FGM/C health care-seeking

\begin{tabular}{|c|c|c|c|c|}
\hline \multirow[t]{2}{*}{ Demographic variables } & \multicolumn{2}{|c|}{ Health care-seeking for FGM/C } & \multirow[t]{2}{*}{ Statistics } & \multirow[t]{2}{*}{$p$-value } \\
\hline & Yes & No & & \\
\hline Place of birth: & & & $x^{2}=0.70$ & 0.40 \\
\hline Born in Norway & $0(0.0)$ & $3(4.8)$ & & \\
\hline Born out of Norway & $14(100)$ & $59(95.2)$ & & \\
\hline Age distribution (years): & & & $X^{2}=0.001$ & 0.97 \\
\hline 16 to 20 & $11(68.8)$ & $43(68.3)$ & & \\
\hline 21 to 25 & $5(31.3)$ & $20(31.7)$ & & \\
\hline Age at migration to Norway & & & $x^{2}=0.02$ & 0.87 \\
\hline 0 to 11 years & $7(43.8)$ & $29(46.0)$ & & \\
\hline$\geq 12$ years & $9(56.3)$ & $34(54.0)$ & & \\
\hline Education: & & & $x^{2}=6.23$ & 0.10 \\
\hline University & $4(25.0)$ & $4(6.6)$ & & \\
\hline Secondary & $9(56.3)$ & $32(52.5)$ & & \\
\hline Primary & $3(18.8)$ & $21(34.4)$ & & \\
\hline Informal education & $0(0.0)$ & $4(6.6)$ & & \\
\hline Marital status: & & & $x^{2}=3.04$ & 0.21 \\
\hline Single & $11(68.8)$ & $51(85.0)$ & & \\
\hline Married & $5(31.3)$ & $8(13.3)$ & & \\
\hline Divorce & $3(0.0)$ & $1(1.7)$ & & \\
\hline Women in support of FGM/C: & & & $X^{2}=0.05$ & 0.81 \\
\hline No & $12(80.0)$ & $52(82.5)$ & & \\
\hline Yes & $3(20.0)$ & $11(17.5)$ & & \\
\hline Women stigmatized of FGM/C practice: & & & $X^{2}=4.34$ & 0.03 \\
\hline No & $9(56.3)$ & $48(81.4)$ & & \\
\hline Yes & $7(43.8)$ & 11 (18.6) & & \\
\hline
\end{tabular}

undergone FGM/C are in support of the practice. Being circumcised may not necessarily mean being supportive of the practice [36]. Parents and family or the duress of social and peer pressure initiated the decision for circumcision in most cases [36, 37]. As most of the young women in the present study had been circumcised prior to migration, it is apparent that most of them were circumcised at an early age based on parental/family decision, as circumcision is a common practice between the ages of 6 and 8 years in Somalia [38]. Growing up in a new environment such as Norway, one would expect that with empowerment and awareness of FGM/C practice over time brings about change that leads the disapproval and discontinuation of the practice.

\section{Health care-seeking}

According to AIC estimates, women's age at migration and the stigma of FGM/C practice were associated with health care-seeking for FGM/C among girls and women who have undergone FGM/C. In our study, we cannot determine which health care service is mostly used for $\mathrm{FGM} / \mathrm{C}$, or the reasons why only $20.3 \%$ of women who have undergone FGM/C have sought care. However, given the lower proportion of women using health care services, might indicate a lack of need or it could be attributed to women's perceptions and challenges of care [20,39].

According to the health belief model, an individual's state of readiness to take action for a health condition is determine by four dimensions. Firstly, the perceived susceptibility to the condition and the probable severity of the condition (defined in terms of physical harm or interfere with social functioning). Secondly, the perception of benefits associated with actions to reduce the level of threat or vulnerability. Thirdly, the assessment of potential barriers, including physical, psychological and financial barriers, and finally, the general health motivations triggering appropriate health behavior, including internal cues as symptoms and external cues like interpersonal interaction and communication [40-42]. Addressing the above concepts of the health belief models both for the women 
Table 5 Logistic regression analyses association of demographic variables, in relation to FGM/C health care-seeking

\begin{tabular}{|c|c|c|c|c|c|c|}
\hline \multicolumn{7}{|c|}{ Health care-seeking for FGM/C } \\
\hline \multirow{3}{*}{$\begin{array}{l}\text { Demographic } \\
\text { variables }\end{array}$} & \multicolumn{2}{|c|}{ Univariate analysis (unadjusted) } & \multirow{2}{*}{\multicolumn{2}{|c|}{$\begin{array}{l}\text { Model } 1 \text { (Adjusted) } \\
{ }^{\mathrm{a}} \mathrm{AIC}=89.97\end{array}$}} & \multirow{2}{*}{\multicolumn{2}{|c|}{$\begin{array}{l}\text { Model } 2 \text { (Adjusted) } \\
{ }^{\mathrm{a}} \mathrm{AIC}=89.91\end{array}$}} \\
\hline & \multirow[b]{2}{*}{ OR $(95 \% \mathrm{Cl})$} & \multirow[b]{2}{*}{$P$-value } & & & & \\
\hline & & & $\mathrm{OR}(95 \% \mathrm{Cl})$ & $P$-value & OR $(95 \% \mathrm{Cl})$ & $P$-value \\
\hline \multicolumn{7}{|c|}{ Age at migration to Norway } \\
\hline 0 to 11 years & 1 & & 1 & & 1 & \\
\hline$\geq 12$ years & $3.25(1.13,9.34)$ & 0.03 & $2.85(0.87,9.41)$ & 0.09 & $3.18(1.02,9.98)$ & 0.05 \\
\hline \multicolumn{7}{|l|}{ Marital status } \\
\hline Single & 1 & & 1 & & 1 & \\
\hline Married & $2.54(0.79,8.13)$ & 0.12 & $3.99(0.98,16.24)$ & 0.053 & $3.43(0.90,13.17)$ & 0.07 \\
\hline Divorce & - & - & - & - & - & - \\
\hline \multicolumn{7}{|l|}{ Education } \\
\hline University & 1 & & 1 & & 1 & \\
\hline Secondary & $0.49(0.13,1.80)$ & 0.29 & $0.28(0.06,1.41)$ & 0.12 & $0.35(0.08,1.61)$ & 0.18 \\
\hline Primary & $0.32(0.06,1.62)$ & 0.17 & $0.18(0.03,1.24)$ & 0.08 & $0.26(0.04,1.51)$ & 0.13 \\
\hline No formal education & - & - & - & - & - & - \\
\hline \multicolumn{7}{|c|}{ Stigmatized of FGM/C practice } \\
\hline No & 1 & & 1 & & 1 & \\
\hline Yes & $3.75(1.26,11.14)$ & 0.02 & $5.03(1.33,18.94)$ & 0.02 & $5.10(1.46,17.79)$ & 0.01 \\
\hline \multicolumn{7}{|l|}{ Age } \\
\hline 16 to 20 years & 1 & & 1 & & & \\
\hline 21 to 25 years & $1.10(0.36,3.36)$ & 0.87 & $0.44(0.10,1.87)$ & 0.27 & & \\
\hline \multicolumn{7}{|c|}{ Support of FGM/C practice } \\
\hline No & 1 & & 1 & & & \\
\hline Yes & $2.14(0.54,8.53)$ & 0.28 & $1.52(0.29,7.93)$ & 0.62 & & \\
\hline
\end{tabular}

Model 1 is a full adjustment for all main demographic variables

Model 2 is based on variables that have $P \leq 0.20$ in the univariate analyses

${ }^{a}$ Model selection was based on the Akaike Information Criterion (AIC) which states that a model with a smaller AIC estimate fits the data better. Therefore, based on the AIC, model 2 was selected

and the health care system could enhance the number of people who use the health care services and assessing the coverage of health services is important to determine the quality of health care services [43].

According to the Norwegian law, it is the duty of parents to ensure that their daughters who have undergone $\mathrm{FGM} / \mathrm{C}$ receive the necessary care [16]. In as much as FGM/C has a complex socio-cultural perspective, a decision to seek care for FGM/C-related issues is contextual. In an African context, as $\mathrm{FGM} / \mathrm{C}$ is associated with culture the decision to seek care lies with the woman herself, her husband and/or relatives. In some settings, health seeking for FGM/C may depend on the availability and the skills of care providers, illness characteristic (recognition and severity), the status of the woman, previous experiences and perceived quality of care [39, 42, 44].

Previous studies have reported FGM/C not to be optimal among migrants in receiving countries. This might be attributed to unskilled care providers in host countries, type of services offered, women's experiences, patients-caregivers interaction and sometimes the costs of care $[39,44,45]$. Health care-seeking may also be affected by a state of vulnerability and traumatization. Care seeking for FGM/C may either enhance or lessen if the women feel embarrassed about their condition, feel inadequate, shy and tense. Revisiting the health services is possible if women were satisfied with the care they received, or their past experiences [46].

According to prior studies, Somalis, Eritrean and $\mathrm{Su}$ danese women with FGM/C in Norway and Sweden, have complained of insufficient attention, support, lack of respect, lack of interpreters, neglect from health care providers and they were uncomfortable with the unpleasant and hurtful comments from caregivers during delivery [20, 34, 47]. Somali women in England, USA and Australia had expressed the feeling of humiliation and avoided questions from health care providers that triggered flashbacks $[48,49]$. Other women with FGM/C were very concerned with the breach of their privacy and confidentiality [50]. It is often presumed that it is 
mandatory for health professionals to inform circumcised women of the care they should expect. However, in Norway, circumcised women complained of lack of information regarding what to expect during delivery [34].

While our data cannot provide the explanations for the findings it is highly likely that the women in our study lack the information and knowledge about access, availability and functioning and navigation of FGM/C related health care services in Norway. Therefore, challenges of care may not only affect the women who are new to Norway, but also those who have been living here for a long period. Furthermore, communication can be a potential barrier to care seeking. Because $96.2 \%$ of the circumcised women were born out Norway, language can hinder their access to seeking care, as language and poor communication have been reported by care providers and women to be a barrier to effective care $[39,51]$. Lack of a well-functioning referral system [52] and a good social support network may also influence access to care. A good support network has been shown to empower FGM/C affected women in accessing antenatal and intrapartum services in England [48]. While some barriers are potentially easier to overcome, there remain some serious concerns regarding the perceptions and experiences of FGM/C affected women that calls for further research.

A step towards health care-seeking might be a step in the direction of the discontinuation of FGM/C, as $85.7 \%$ of FGM/C affected women from Somalia, have previously indicated their interest in the discontinuity of FGM/C practice [53]. We observed FGM/C prevalence of $51.6 \%$, in our study indicating a significant decline among the younger age groups, compared to a higher prevalence of $79.3 \%$ among older age group in a prior study [17]. This is consistent with other reports of the discontinuation of FGM/C in Somali communities, both at home and abroad [50, 54, 55]. Readiness to seek help might indicate that these women trust the patientcentered care and/or the Norwegian health care system and that the health personnel are responsive to their needs and values. It could also indicate that the health care centers/ support centers might provide solace as well as access to information and educational resources.

Although fewer numbers of women used the health care services, it is worth highlighting that there was a significant association between women who felt stigmatized by the practice and health care-seeking. Although stigmatization has often been pointed out as a deterrent to seeking medical care among FGM/C affected women $[9,47,56,57]$, it is noteworthy stigma was not a barrier to health care-seeking in the present study. As most (56. $7 \%$ ) of these women have at least secondary education, they may have acquired knowledge of the negative effects of the practice through awareness campaigns in
Norway. Good knowledge along with willingness to seek care despite the stigma of the practice could indicate changing attitudes and perceptions towards FGM/C. It may also indicate a readiness for compliance to address their health needs [58].

The age at migration to Norway influenced women's use of FGM/C health care in our study. Those who arrived at a young age were less likely to seek care, one would expect that they may not need care or may not know if the services are provided. Even if they are aware of the services, they may be faced with difficulty in navigating the health care system. The fear of criminalization has been previously documented as a limitation to accessing much needed quality health services in host countries $[9,57]$. However, we are unable to study this association in our study population as most of the affected women were circumcised prior to migration and we did not ask any direct questions related to the fear of criminalization as being a barrier to health seeking.

\section{Strength and limitation of the study}

The strength of the study lies in using the RDS methodology, pretesting of data collection tools, recruitment of field workers trusted by the Somali community and adequate training of the field workers. Because the principal investigator and the data collectors spoke the same language, this rules out bias due to translation. While it is impossible to rule out selection bias using our sampling methods, nonetheless, the findings provide valuable information about those seeking care for their health problems. However, our study is limited in providing explanations as to why this is the case. We have not ascertained information such as the degree of FGM/ $\mathrm{C}$ or the symptoms and that limits our interpretations.

\section{Conclusion}

We have found that the proportion of women seeking care for FGM/C-related health problems is very low compared to the number of women with $\mathrm{FGM} / \mathrm{C}$ but our study is unable to provide the explanations as to why this is the case. Therefore, it would be desirable to conduct further research targeting girls and women who have been subjected to FGM/C to investigate access problems for FGM/C health care-seeking. The insights gained are likely to be valuable and can serve as baseline information for further research and appropriate interventions for health seeking.

\section{Abbreviations}

AIC: Akaike Information Criterion; Cl: Confidence Interval; FGM/C: Female genital mutilation/cutting; GLMs: Generalized linear regression models; GP: General Practitioner; NOK: Norwegian Kroner; OR: Odds Ratio; PTSD: Posttraumatic stress disorder; RDS: Respondent-Driven Sampling; REK: Regional Committee for Medical and Health Research Ethics; SD: Standard deviation; SSD: Social Science Data registry; WHO: World Health Organization 


\section{Acknowledgements}

We thank the University of Oslo for their financial support and Dr. Berit Austveg for her valuable comments.

\section{Funding}

University of Oslo (UiO), Norway.

\section{Availability of data and materials}

The datasets generated and/or analyzed during the current study are not publicly available due to confidential reasons. The datasets are under the management of the Norwegian Center for Minority Health Research Oslo, but are available from the corresponding author on reasonable request.

\section{Authors' contributions}

VNM was responsible for the data analysis, interpretation of the results and the writing of the manuscript. AAG was involved in the design of the study and contributed to the interpretation of the results. ED and BK contributed in the interpretation of the results. VNM, AAG, ED and BK critically revised the manuscript for important intellectual content. All authors read and approved the final manuscript.

\section{Ethics approval and consent to participate}

This study is part of the project "Access and use of health care services among immigrants from sub-Saharan African in Norway" ethically approved by the Norwegian Regional Committee for Medical and Health Research Ethics (2016/ 799/REK vest). The participants of this study were from a cross-sectional study conducted in 2014 in Oslo, which was approved by REK and Social Science Data registry (SSD) and informed consent was obtained.

\section{Competing interests}

The authors declare that they have no competing interests.

\section{Publisher's Note}

Springer Nature remains neutral with regard to jurisdictional claims in published maps and institutional affiliations.

\section{Author details}

${ }^{1}$ Department of Community Medicine and Global health, Institute of Health and Society, Faculty of Medicine, University of Oslo, P.O Box 1130, Blindern, 0318 Oslo, Norway. ${ }^{2}$ Department of Nursing and Health Promotion, Faculty of Health Sciences, Oslo and Akershus University College of Applied Sciences, Oslo, Norway. ${ }^{3}$ Norwegian Centre for Minority Health Research, Oslo, Norway. ${ }^{4}$ Department of Global Public Health and Primary Care, University of Bergen, Bergen, Norway.

\section{Received: 27 April 2017 Accepted: 11 April 2018}

\section{Published online: 18 April 2018}

\section{References}

1. WHO. Eliminating female genital mutilation an interagency statementOHCHR, UNAIDS, UNDP, UNECA, UNESCO, UNFPA, UNHCR, UNICEF, UNIFEM, WHO. GENEVA: WHO; 2008.

2. WHO. Female Genital Mutilation: 2016. http://www.who.int/topics/female_ genital_mutilation/en/.

3. UNICEF. Female genital mutilation/cutting: a statistical overview and exploration of the dynamics of change. 2013.

4. Teixeira AL, Lisboa M. Estimating the prevalence of female genital mutilation in Portugal. Public Health. 2016; https://doi.org/10.1016/j. puhe.2016.05.002

5. Garba ID, Muhammed Z, Abubakar IS, Yakasai IA. Prevalence of female genital mutilation among female infants in Kano, northern Nigeria. Arch Gynecol Obstet. 2012;286(2):423-8.

6. Isa AR, Shuib R, Othman MS. The practice of female circumcision among Muslims in Kelantan, Malaysia. Reprod Health Matters. 1999;7(13):137-44

7. Banks E, Meirik O, Farley T, Akande O, Bathija H, Ali M. Female genital mutilation and obstetric outcome: WHO collaborative prospective study in six African countries. Lancet. 2006:367(9525):1835-41.

8. Vloeberghs E, van der Kwaak A, Knipscheer J, van den Muijsenbergh M. Coping and chronic psychosocial consequences of female genita mutilation in the Netherlands. Ethn Health. 2012;17(6):677-95.
9. Vissandjee B, Kantiebo M, Levine A, N'Dejuru R. The cultural context of gender, identity: female genital, excision and infibulation. Health Care Women Int. 2003;24(2):115-24.

10. Fahmy A, El-Mouelhy MT, Ragab AR. Female genital mutilation/cutting and issues of sexuality in Egypt. Reprod Health Matters. 2010;18(36):181-90.

11. Berg RC, Underland V, Odgaard-Jensen J, Fretheim A, Vist GE. Effects of female genital cutting on physical health outcomes: a systematic review and meta-analysis. BMJ Open. 2014;4(11):e006316.

12. Elnashar A, Abdelhady R. The impact of female genital cutting on health of newly married women. Int J Gynaecol Obstet. 2007;97(3):238-44.

13. Hodes D, Armitage A, Robinson K, Creighton SM. Female genital mutilation in children presenting to a London safeguarding clinic: a case series. Arch Dis Child. 2016;101(3):212-6.

14. Organization WH. Female genital mutilation fact sheet. 2016

15. Jungari SB. Female genital mutilation is a violation of reproductive rights of women: implications for health workers. Health Soc Work. 2016;41(1):25-31.

16. The Norwegian Directorate of Immigration. Female Genital Mutilation 2016: https://www.udi.no/en/word-definitions/female-genital-mutilation-/.

17. Ziyada MM, Norberg-Schulz M, Johansen RE. Estimating the magnitude of female genital mutilation/cutting in Norway: an extrapolation model. BMC Public Health. 2016;16:110

18. Nordic Federation of Societies of Obstetrics and Gynaecology: https://nfog. org/. Accessed 20 Aug 2017.

19. Bhuiya A. Health for the rural masses: insights from Chakaria. Dhaka: International Centre for Diarrhoeal Disease Research; 2009.

20. Johansen RE. Care for infibulated women giving birth in Norway: an anthropological analysis of health workers' management of a medically and culturally unfamiliar issue. Med Anthropol Q. 2006;20(4):516-44.

21. Heckathorn D. Respondent-driven sampling: a new approach to the study of hidden populations. Soc Probl. 1997:44:179-99.

22. Salganik MDJ, Heckathorn D. Sampling and estimation in hidden populations using respondent-driven sampling. Sociol Methodol. 2004:34: 193-239.

23. Johnston LG, Malekinejad M, Kendall C, luppa IM, Rutherford GW. Implementation challenges to using respondent-driven sampling methodology for HIV biological and behavioral surveillance: field experiences in international settings. AIDS Behav. 2008;12(4 Suppl):S131-41.

24. Brouwer KC, Lozada R, Cornelius WA, Firestone Cruz M, Magis-Rodriguez C, Zuniga de Nuncio ML, et al. Deportation along the U.S.-Mexico border: its relation to drug use patterns and accessing care. J Immigr Minor Health. 2009;11(1):1-6.

25. Doocy S, Malik S, Burnham G. Experiences of Iraqi doctors in Jordan during conflict and factors associated with migration. Am J Disaster Med. 2010;5(1):41-7.

26. Montealegre JR, Risser JM, Selwyn BJ, McCurdy SA, Sabin K. Prevalence of HIV risk behaviors among undocumented central American immigrant women in Houston, Texas. AIDS Behav. 2012;16(6):1641-8.

27. Rhodes SD, McCoy TP, Hergenrather KC, Vissman AT, Wolfson M, Alonzo J, et al. Prevalence estimates of health risk behaviors of immigrant latino men who have sex with men. J Rural Health. 2012;28(1):73-83.

28. Elgaali M, Strevens H, Mardh PA. Female genital mutilation - an exported medical hazard. Eur J Contracept Reprod Health Care. 2005;10(2):93-7.

29. Litorp H, Franck M, Almroth L. Female genital mutilation among antenatal care and contraceptive advice attendees in Sweden. Acta Obstet Gynecol Scand. 2008:87(7):716-22.

30. Dubourg D, Richard F, Leye E, Ndame S, Rommens T, Maes S. Estimating the number of women with female genital mutilation in Belgium. Eur J Contracept Reprod Health Care. 2011;16(4):248-57.

31. Gordon H, Comerasamy H, Morris NH. Female genital mutilation: experience in a West London clinic. J Obstet Gynaecol. 2007;27(4):416-9.

32. Gajaa M, Wakgari $N$, Kebede $Y$, Derseh L. Prevalence and associated factors of circumcision among daughters of reproductive aged women in the Hababo Guduru District, western Ethiopia: a cross-sectional study. BMC Womens Health. 2016:16:42.

33. Farina $P$, Ortensi LE, Menonna A. Estimating the number of foreign women with female genital mutilation/cutting in Italy. Eur J Pub Health 2016;26(4):656-61

34. Vangen S, Johansen RE, Sundby J, Traeen B, Stray-Pedersen B. Qualitative study of perinatal care experiences among Somali women and local health care professionals in Norway. Eur J Obstet Gynecol Reprod Biol. 2004;112(1):29-35. 
35. Nuse IP. Why is nobody convicted of genital mutilation in Norway?. 2017. Avaliable via: http://sciencenordic.com/why-nobody-convicted-genitalmutilation-norway.

36. Pashaei T, Ponnet K, Moeeni M, Khazaee-pool M, Majlessi F. Daughters at risk of female genital mutilation: examining the determinants of Mothers' intentions to allow their daughters to undergo female genital mutilation. PLoS One. 2016;11(3):e0151630

37. Belizan JM, Miller S, Salaria N. We need to stop female genital mutilation. Reprod Health. 2016;13:43.

38. Land Info Country of origin information center: Female genital mutilation in Sudan and Somalia. Available via: https://landinfo.no/asset/764/1/764_1.pdf. Accessed 20 Aug 2017.

39. Lazar JN, Johnson-Agbakwu CE, Davis Ol, Shipp MP. Providers' perceptions of challenges in obstetrical care for Somali women. Obstet Gynecol Int. 2013:2013:149640.

40. Harrison JA, Mullen PD, Green LW. A meta-analysis of studies of the health belief model with adults. Health Educ Res. 1992;7(1):107-16.

41. Bates AS, Fitzgerald JF, Wolinsky FD. Reliability and validity of an instrument to measure maternal health beliefs. Med Care. 1994;32(8):832-46.

42. Andersen RM. Revisiting the behavioral model and access to medical care: does it matter? J Health Soc Behav. 1995;36(1):1-10.

43. Tanahashi T. Health service coverage and its evaluation. Bull World Health Organ. 1978;56(2):295-303

44. Leye E, Ysebaert I, Deblonde J, Claeys P, Vermeulen G, Jacquemyn Y, et al. Female genital mutilation: knowledge, attitudes and practices of Flemish gynaecologists. Eur J Contracept Reprod Health Care. 2008:13(2):182-90.

45. Purchase TC, Lamoudi M, Colman S, Allen S, Latthe P, Jolly K. A survey on knowledge of female genital mutilation guidelines. Acta Obstet Gynecol Scand. 2013;92(7):858-61.

46. Widmark C, Tishelman C, Ahlberg BMA. Study of Swedish midwives' encounters with infibulated African women in Sweden. Midwifery. 2002; 18(2):113-25.

47. Berggren V, Bergstrom S, Edberg AK. Being different and vulnerable: experiences of immigrant African women who have been circumcised and sought maternity care in Sweden. J Transcult Nurs. 2006;17(1):50-7.

48. Moxey JM, Jones LL. A qualitative study exploring how Somali women exposed to female genital mutilation experience and perceive antenatal and intrapartum care in England. BMJ Open. 2016;6(1):e009846.

49. Dawson AJ, Turkmani S, Varol N, Nanayakkara S, Sullivan E, Homer CS. Midwives' experiences of caring for women with female genital mutilation: insights and ways forward for practice in Australia. Women Birth. 2015;28(3):207-14.

50. Khaja K, Lay K, Boys S. Female circumcision: toward an inclusive practice of care. Health Care Women Int. 2010:31(8):686-99.

51. Berggren V, Abdel Salam G, Bergström S, Johansson E, Edberg A-K. An explorative study of Sudanese midwives' motives, perceptions and experiences of re-infibulation after birth. Midwifery. 2004;20(4):299-311.

52. Mujasi PN, Asbu EZ, Puig-Junoy J. How efficient are referral hospitals in Uganda? A data envelopment analysis and tobit regression approach. BMC Health Serv Res. 2016;16:230.

53. Gele AA, Johansen EB, Sundby J. When female circumcision comes to the west: attitudes toward the practice among Somali immigrants in Oslo. BMC Public Health. 2012;12:697.

54. Gele AA, Bo BP, Sundby J. Attitudes toward female circumcision among men and women in two districts in Somalia: is it time to rethink our eradication strategy in Somalia? Obstet Gynecol Int. 2013;2013:312734

55. Gele AA, Kumar B, Hjelde KH, Sundby J. Attitudes toward female circumcision among Somali immigrants in Oslo: a qualitative study. Int J Womens Health. 2012:4:7-17.

56. Fried S, Mahmoud Warsame A, Berggren V, Isman E, Johansson A. Outpatients' perspectives on problems and needs related to female genital mutilation/cutting: a qualitative study from somaliland. Obstet Gynecol Int. 2013;2013:165893.

57. Abusharaf RM. Female Circumcision: Multicultural Perspectives. Philadelphia: University of Pennsylvania Press; 2006.

58. Mahmoud MIH. Effect of female genital mutilation on female sexual function, Alexandria, Egypt. Alexandria Journal of Medicine. 2016;52(1):55-9.

\section{Ready to submit your research? Choose BMC and benefit from:}

- fast, convenient online submission

- thorough peer review by experienced researchers in your field

- rapid publication on acceptance

- support for research data, including large and complex data types

- gold Open Access which fosters wider collaboration and increased citations

- maximum visibility for your research: over $100 \mathrm{M}$ website views per year

At BMC, research is always in progress.

Learn more biomedcentral.com/submissions 